\title{
The intermediate performance of territories of priority socio-economic development in Russia in conditions of macroeconomic instability
}

\author{
Sergey Beliakov ${ }^{1, *}$, Anna Kapustkina ${ }^{1}$ \\ ${ }^{1}$ Moscow state university of civil engineering, YaroslavskoyeShosse, 26, Moscow, 12933, Russia
}

\begin{abstract}
The Russian economy in recent years has faced the influence of a number of negative factors due to macroeconomic instability and increased foreign policy tensions. In these conditions the considerable constraints faced processes of socio-economic development of regions of the Russian Federation. In this article the authors attempt to analyze the key indicators of socio-economic development of the regions in which it was created and operate in the territories of priority socio-economic development. These territories are concentrated in the Far Eastern Federal District. The article identified, processed, and interpreted indicators, allowing to produce a conclusion on the interim effectiveness of the territories of priority socio-economic development in Russia in conditions of macroeconomic instability.
\end{abstract}

\section{Introduction}

The main purpose of socio-economic policy is to increase the standard of living, increasing prosperity and ensuring social guarantees to the population. Without these indicators, it is impossible to imagine the effective development of civil society and of the economy as a whole. The crisis in macroeconomics and world politics led to the deterioration of the General economic situation in Russia and, as consequence, decrease in level of living of the population $[1,2]$.

\section{Experimental section}

Statistics show that in most Russian regions indicators of the level of living of the population significantly differ from similar indicators in the regional centers. The following are the first 10 positions of the rating of socio-economic status of subjects of the Russian Federation by the end of 2015 (Table 1). Integral rating of the region consists of the following indicators:

- volume of production of goods and services (billion rubles);

- the volume of consolidated budget revenues (billion rubles);

- the number of people employed in economy (thousands of people).

${ }^{*}$ Corresponding author: serj-bel@yandex.ru 
- volume of production of goods and services per capita (thousand rubles);

- the volume of investments in fixed capital per capita (thousand rubles);

- the percentage of profitable companies (\%);

- the ratio of debt on taxes to the amount received in taxes and fees to the budget system of the Russian Federation (\%);

- share of income of consolidated budget per capita (thousand rubles);

- the share of tax and non-tax revenues in the total revenues of the consolidated budget $(\%)$;

- the ratio of public debt to tax and non-tax revenues of the consolidated budget (\%);

- the ratio of the deficit / surplus to tax and non-tax revenues of the consolidated budget $(\%)$;

- the ratio of money incomes to the cost of the fixed set of consumer goods and services (times);

- unemployment rate (\%).

Table 1. The rating of socio-economic status the subjects of the Russian Federation by the end of 2015.

\begin{tabular}{|c|c|c|}
\hline $\begin{array}{c}\text { Place by the } \\
\text { end of 2015 }\end{array}$ & Subjects of the Russian Federation & $\begin{array}{c}\text { Integrated rating at the } \\
\text { end of 2015 in points }\end{array}$ \\
\hline 1 & Moscow & 82.144 \\
\hline 2 & Saint-Petersburg & 74.564 \\
\hline 3 & Khanty-Mansi Autonomous Okrug - Yugra & 72.871 \\
\hline 4 & Moscow region & 68.182 \\
\hline 5 & The Republic Of Tatarstan & 66.923 \\
\hline 6 & Yamalo-Nenets Autonomous Okrug & 64.581 \\
\hline 7 & Sakhalin region & 62.917 \\
\hline 8 & Tyumen region & 61.367 \\
\hline 9 & Sverdlovsk region & 59.486 \\
\hline 10 & Republic of Bashkortostan & 59.352 \\
\hline
\end{tabular}

In order to stabilize and enhance regional socio-economic development of the Government of the Russian Federation adopted a number of laws, including Federal law dated 29 December 2014 No. 473-FZ "About territories of priority socio-economic development in the Russian Federation".

According to this law, the territory of priority socio-economic development (TPSED) part of the territory of the Russian Federation, including closed administrative-territorial unit where in accordance with the decision of the Government of the Russian Federation established a special legal regime of entrepreneurial and other activities in order to create favorable conditions for attracting investments, ensuring accelerated socio-economic development and create favorable conditions for the viability of the population [3].

It was planned that during the first three years of the period of validity of the law of the territory of priority socio-economic development will operate only on the territory of the Far Eastern Federal District (FEFD), however, currently considers the possibility of their creation on the territory of the Republic of Tatarstan (NaberezhnyeChelny city) and in several other areas[4-6].

According to the authors of the article, the decision of the Russian Government to create a territory of priority socio-economic development primarily in FEFD due to several reasons:

1. attempt to reduce the outflow of population from the territory of FEFD;

2. significant unrealized resource potential of the territories;

3. the proximity of the Asia-Pacific region (APR), which determines the possibilities of development of international economic relations; 
4. the attractiveness of the territory FEFD for investors from APR.

In the FEFD includes the following regions: Amur oblast, Jewish Autonomous oblast, Kamchatka Krai, Magadan oblast, PrimorskyKrai, Republic of Sakha (Yakutia), Sakhalin oblast, Khabarovsk Krai, Chukotka Autonomous Okrug. Area of FEFD is 36\% of the area of the whole country [7-10].

To date, there are 13 territories of priority socio-economic development. Distribution of TPSED on the subjects of the Russian Federation is presented inTable 2.

Table 2. The distribution of areas of priority socio-economic development of subjects of the Far Eastern Federal District.

\begin{tabular}{|c|c|c|}
\hline Subject of FEFD & $\begin{array}{c}\text { The number of TPSED in the } \\
\text { territory of the subject }\end{array}$ & Year of creation \\
\hline Sakhalin oblast & 2 & 2016 \\
\hline $\begin{array}{c}\text { The Republic Of Sakha } \\
\text { (Yakutia) }\end{array}$ & 1 & 2015 \\
\hline PrimorskyKrai & 3 & $2015-2016$ \\
\hline Khabarovsk Krai & 2 & 2015 \\
\hline Amur oblast & 2 & 2015 \\
\hline Kamchatka Krai & 1 & 2016 \\
\hline $\begin{array}{c}\text { Chukotka Autonomous } \\
\text { Okrug }\end{array}$ & 1 & 2016 \\
\hline Jewish Autonomous oblast & 1 & \\
\hline
\end{tabular}

Consider the dynamics of the development of each of the constituent entities of the Russian Federation in the period from 2012 to 2015 in the following key socio-economic indicators:

1. per capita income (per month);

2. the level of unemployment;

3. investment in fixed capital.

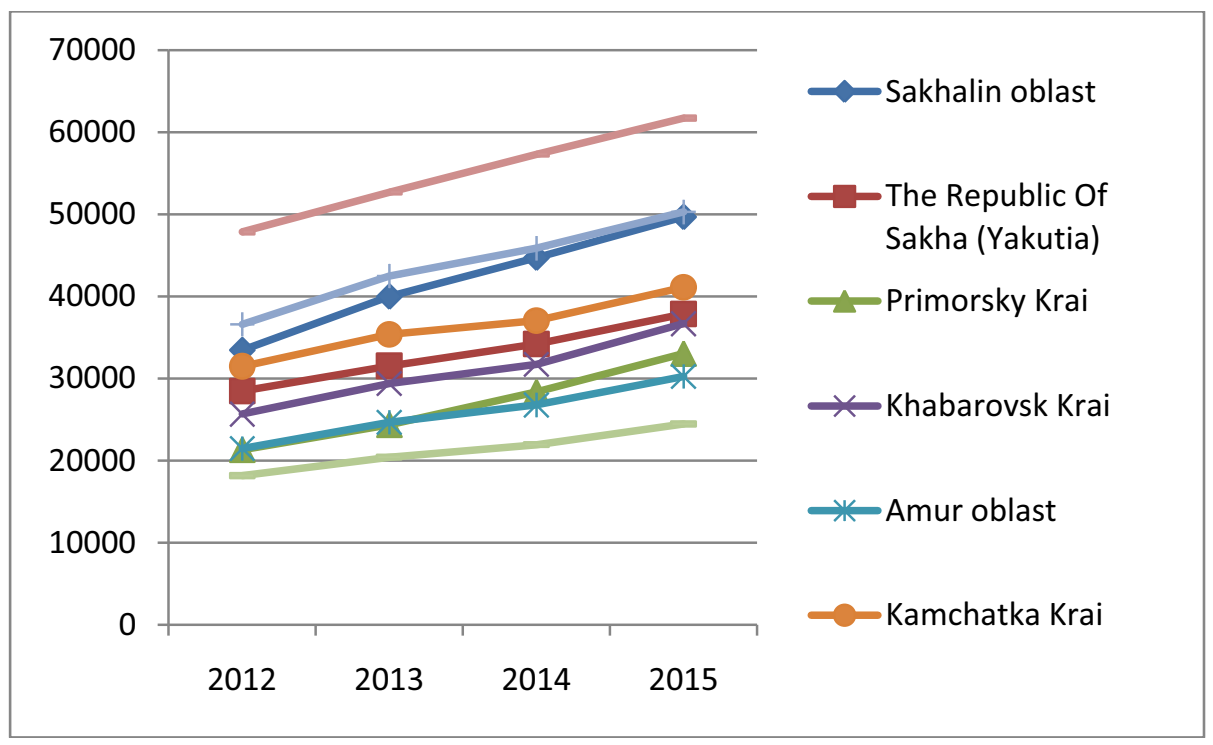

Fig. 1. Dynamics of the indicator per capita income (per month) from 2012 to 2015 in the subjects of the Far Eastern Federal District. 


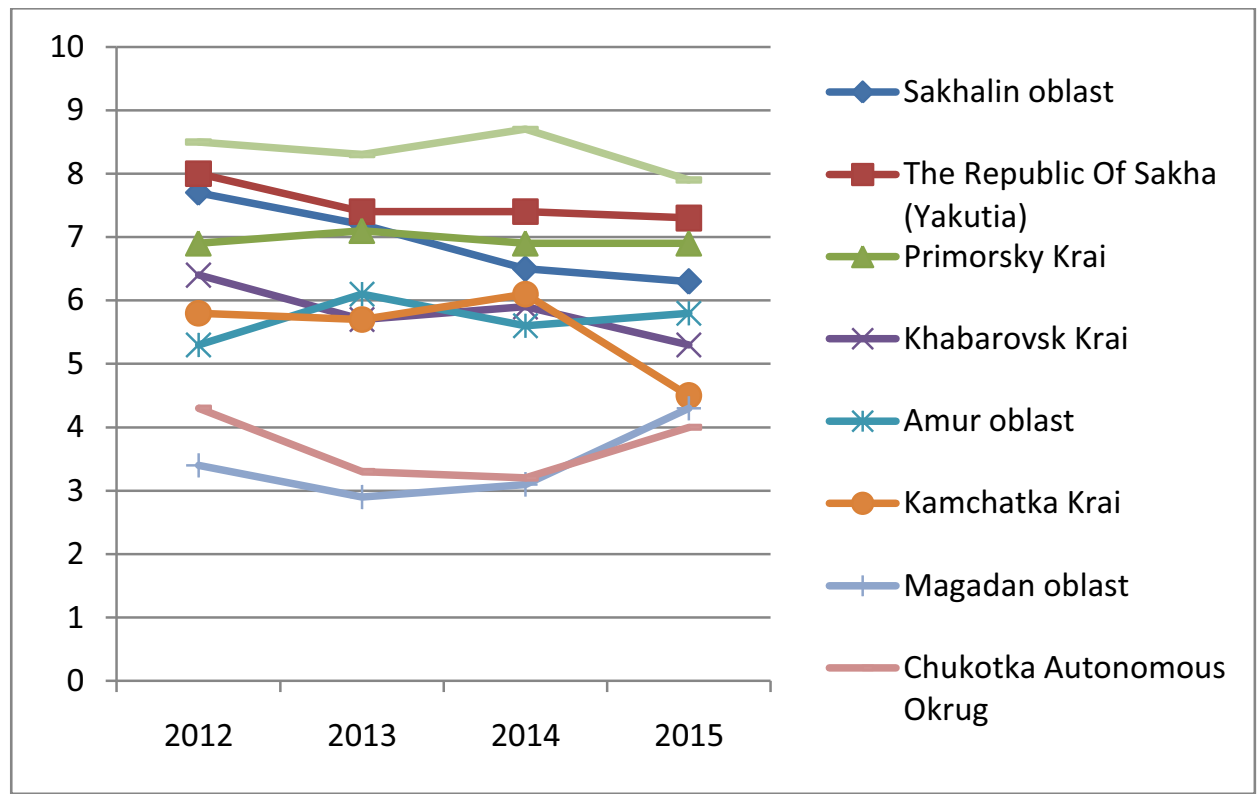

Fig. 2. Dynamics of the level of unemployment from 2012 to 2015 in the subjects of the Far Eastern Federal District (\%).

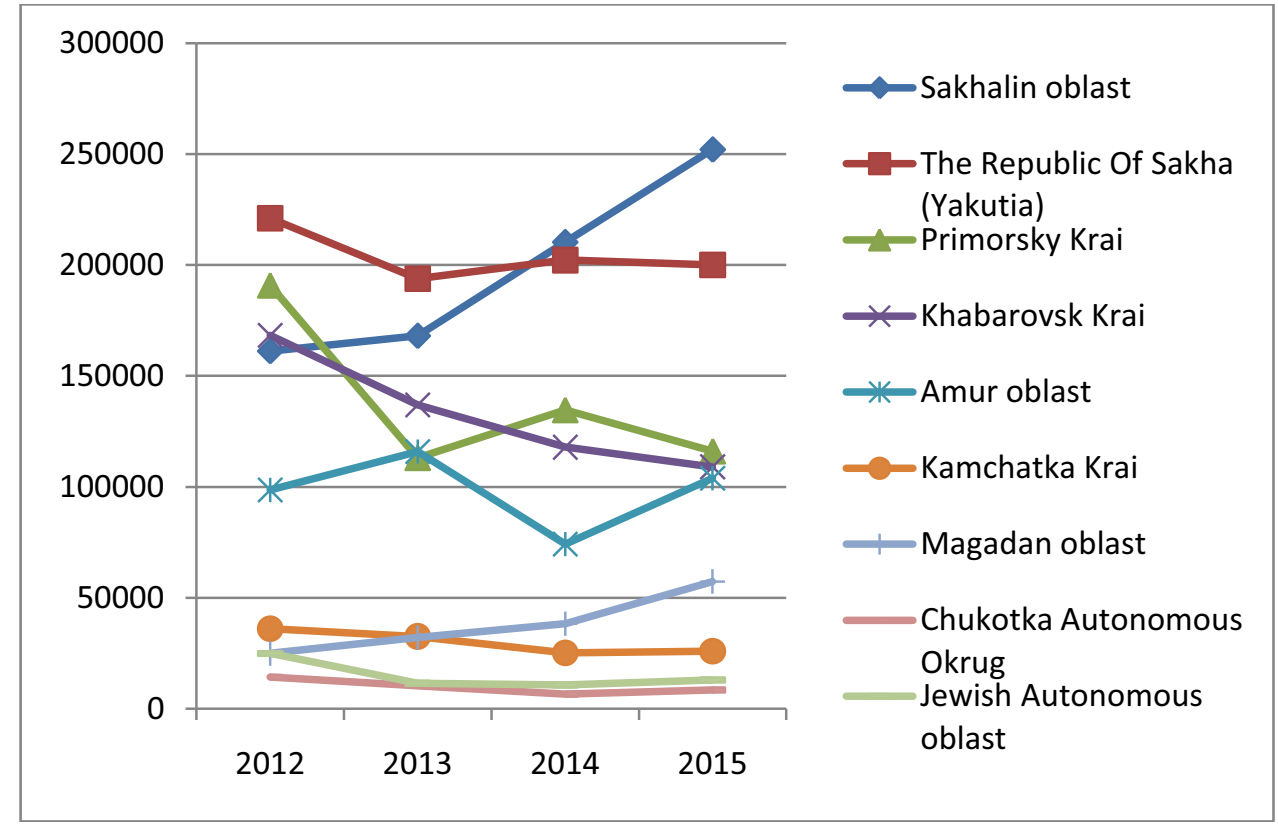

Fig. 3. Dynamics of the indicator investment in fixed capital from 2012 to 2015 in the subjects of the Far Eastern Federal District (million RUB).

\section{Results section}

According to the analysis, we can conclude that the subjects of the FEFD are stable indicators of socio-economic development, the value of which can be described. Positive trends include an increase in per capita incomes and lower unemployment in some of the 
regions. [11-14]

However, given the negative macroeconomic and international environment in the period considered, in the opinion of the authors, when assessing the dynamics of indicators of socio-economic development of regions it is useful to consider not the absolute values of the individual indicators and the corresponding changes of relative positions of regions in the consolidated rating of the subjects of the Russian Federation. [1]

Table 3 presents the comparative performance of the regions of FEFD at the end of 2014-2015, in the framework of rating the socio-economic situation of subjects of the Russian Federation.

Table 3. The rating of socio-economic status the subjects of the Far Eastern Federal District by results 2014-2015.

\begin{tabular}{|c|c|c|c|}
\hline $\begin{array}{c}\text { Place } \\
\text { by the } \\
\text { end of } \\
\mathbf{2 0 1 4}\end{array}$ & $\begin{array}{c}\text { By the end } \\
\text { of 2015 }\end{array}$ & Subject of FEFD & $\begin{array}{c}\text { Integrated rating at the } \\
\text { end of 2015 in points }\end{array}$ \\
\hline 8 & 7 & Sakhalin oblast & 62.917 \\
\hline 20 & 21 & The Republic Of Sakha (Yakutia) & 53.103 \\
\hline 29 & 27 & PrimorskyKrai & 48.595 \\
\hline 40 & 33 & Khabarovsk Krai & 46.956 \\
\hline 61 & 51 & Amur oblast & 39.507 \\
\hline 60 & 57 & Kamchatka Krai & 36.521 \\
\hline 64 & 64 & Magadan oblast & 31.658 \\
\hline 73 & 67 & Chukotka Autonomous Okrug & 29.920 \\
\hline 82 & 84 & Jewish Autonomous oblast & 13.755 \\
\hline
\end{tabular}

\section{Conclusion}

As can be seen from Table 3, the indicators of the majority of subjects DFO in the territories which operate an FEFD at the end of 2015 showed positive dynamics compared to the corresponding figures in 2014. These results, according to the authors, can serve as confirmation of the effectiveness of TPSED as a tool for socio-economic development of territories in a negative and unstable macroeconomic conditions.

In General, we can conclude that the functioning of areas of prioritysocio-economic development in the district contributes to the formation of favorable conditions for attracting investments, ensuring socio-economic development and creation of comfortable life conditions.

\section{References}

1. I. Malganova, H.Zagladina, Procedia Economics and Finance24, 371-375 (2015)

2. Y.Vertakova, I.Risin, Procedia Economics and Finance 27, 538-547 (2015)

3. D.Miljkovic, A.Glazyrina, Journal of Policy Modeling 37, 961-973 (2015)

4. I.Malganova, H.Zagladina, Procedia Economics and Finance 27, 64-68 (2015)

5. I.V. Gukalova, S.A. Lisovsky, E.A. Maruniak, K.N. Misevich, L.G. Rudenko, S.V. Ryashchenko, Geography and Natural Resources 30, 300-305 (2009)

6. S.Malle, J. Cooper, Journal of Eurasian Studies5, 21-38 (2014)

7. R.Sadyrtdinov, M.Korablev, S.Vladimirova, Procedia Economics and Finance 24, 557562 (2015)

8. R.Lee, Orbis57, 314-324 (2013) 
9. Z.I. Sidorkina, G.Sh. Tsitsiashvili, Geography and Natural Resources 30, 383-387 (2009)

10. I.E. Nikulina, I.V. Khomenko, Procedia - Social and Behavioral Sciences 166, 142-146 (2015)

11. V.Artamonov, L.Vorona-Slivinskaya, A.Medvedeva, Procedia Engineering 165, 1192 1196 (2016)

12. N.Kalenskaya, Social and Behavioral Sciences 177, 203-208 (2015)

13. D.Medvedev, Russian Journal of Economics 2, 327-348 (2016)

14. L.A. Bezrukov, L.M. Korytny, Geography and Natural Resources 30, 229-235 (2009) 